\title{
Possibilities of Creating Net Zero Carbon Emissions Prisons in the Island of Crete, Greece
}

\author{
John Vourdoubas \\ Mediterranean Agronomic Institute of Chania, Chania, Greece \\ Email: vourdoubas@chania.teicrete.gr
}

How to cite this paper: Vourdoubas, J. (2020) Possibilities of Creating Net Zero Carbon Emissions Prisons in the Island of Crete, Greece. Open Journal of Energy Efficiency, 9, 81-93.

https://doi.org/10.4236/ojee.2020.92006

Received: January 3, 2020

Accepted: April 23, 2020

Published: April 26, 2020

Copyright $\odot 2020$ by author(s) and Scientific Research Publishing Inc. This work is licensed under the Creative Commons Attribution International License (CC BY 4.0).

http://creativecommons.org/licenses/by/4.0/

\begin{abstract}
An increase in energy efficiency and a reduction of carbon emissions in buildings are prerequisites for mitigating climate change. Public buildings should be energy-refurbished for minimizing their energy use, complying with EU legislation and directives. The creation of net zero carbon emissions prisons in Crete, Greece with reference to the agricultural prison of Agia has been examined. The prison's capacity is 178 offenders and the annual energy consumption has been estimated at $4000 \mathrm{KWh} /$ prisoner. The use of a solar thermal system for hot water production and a solar-PV system for electricity generation has been proposed for generating the energy required in the prison. Two scenarios have been examined. In the first, the two solar energy systems would generate all the required energy in the prison, while in the second, the two solar energy systems would generate $50 \%$ of the annual required energy in the prison, and the rest would be produced by fossil fuels. A tree plantation, either with olive trees or with Eucalyptus trees, would be created for offsetting the carbon emissions due to fossil fuels used in the prison. The surface of the flat plate solar collectors in the solar thermal system has been estimated at $113.9 \mathrm{M}^{2}$ to $227.8 \mathrm{M}^{2}$ while its cost is at $34,170 €$ to $68,340 €$. The nominal power of the solar-PV system has been estimated at $151.9 \mathrm{KW}_{\mathrm{p}}$ to $303.8 \mathrm{KW}_{\mathrm{p}}$ while its cost is at $182,280 €$ to $364,560 €$. The area of the tree plantation sequestrating $50 \%$ of the current $\mathrm{CO}_{2}$ emissions due to fossil fuels use in the prison has been estimated at 14.74 ha for olive trees and at 5.9 ha for Eucalyptus trees. The results indicated that the energy refurbishment in Agia's agricultural prison in Crete, Greece, in order to zero its annual net carbon emissions, is feasible.
\end{abstract}

\section{Keywords}

Carbon Emissions, Crete-Greece, Prisons, Renewable Energies, Tree Plantations 


\section{Introduction}

The global threat of climate change requires the change in the fossil fuels used during the last two hundred years and the transition towards benign renewable energy resources. Public buildings consume large amounts of energy; among them are included prisons and correction buildings. Current European and Greek legislation obligates the energy renovation of prison buildings and their transformation towards nearly zero-energy buildings. Reports on the use of sustainable energies in prisons are limited so far while studies regarding the reduction of energy consumption and carbon emissions in Greek prisons are lacking. The possibility of using renewable energy technologies (RET) for heat and power generation in prisons is investigated with reference to a prison located in Crete, Greece. Locally available renewable energies could be used for that, resulting in minimizing or zeroing the prison's carbon footprint due to energy use. Energy refurbishment of public buildings like hospitals, schools and prisons reducing their energy consumption and carbon emissions is important and compulsory in order to improve their energy efficiency and to mitigate climate change complying with the global, European and national targets and goals set.

\subsection{Energy Consumption in Prisons}

The energy sustainability in prisons through the implementation of the project E-SEAP financed by the EU has been studied [1]. The authors mentioned that the average annual energy in prisons located in seven EU countries varies from $4000 \mathrm{KWh} /$ prisoner to $16,500 \mathrm{KWh} /$ prisoner while their annual carbon emissions varied between 0.6 tn $\mathrm{CO}_{2} /$ prisoner and 4 tn $\mathrm{CO}_{2} /$ prisoner. Annual energy consumption in Greek prisons has been reported at $4000 \mathrm{KWh} /$ prisoner while their annual carbon emissions are at 1.2 tn $\mathrm{CO}_{2}$ /prisoner. They also stated that the building stock of EU prisons is old and their energy consumption is high while the possibility for energy renovation in their buildings is limited. The energy consumption profile of the existing building stock in Greece has been reported [2]. The author mentioned that the total annual primary energy consumption in prisons is at $663.48 \mathrm{KWh} / \mathrm{m}^{2}$. It was also stated that the share of electricity in their total energy consumption is at $73.41 \%$, of heating oil at $25.27 \%$, of natural gas at $1.03 \%$ and of solar energy at $0.71 \%$. Energy efficiency in correctional facilities in the USA has been studied [3]. The author mentioned that the annual primary energy intensity in prisons is at $535.2 \mathrm{KWh} / \mathrm{m}^{2}$ while their on-site energy intensity is at $293.6 \mathrm{KWh} / \mathrm{m}^{2}$. It was also stated that prisons should ask support from state energy offices in the implementation of sustainable energy projects due to the high capital required and the necessity for qualified energy expertise. A report on four existing prisons located in Crete, Greece has been published [4]. The report mentioned that the capacity of the existing prisons in Crete is as follows: Chania prison-480 offenders, Agia prison-178 offenders, Nea Alikarnasos prison-210 offenders and Neapoli prison-45 offenders. Various definitions of zero energy buildings have been reported [5]. The 
authors mentioned four definitions as follows: net zero site energy, net zero source energy, net zero energy costs and net zero energy emissions. A net zero energy emissions building, according to them, produces at least as much emissions-free renewable energy as it uses from emissions-producing energy sources. An overview on the life cycle of buildings has been presented [6]. The authors analyzed the results of 73 cases from 13 countries including residential and office buildings. They found that operating energy corresponds to $80 \%-90 \%$ of the life cycle energy use and the rest corresponds to embodied energy. They estimated the annual life cycle primary energy requirements at $150-400 \mathrm{KWh} / \mathrm{m}^{2}$ for residential buildings and $250-550 \mathrm{KWh} / \mathrm{m}^{2}$ for offices. A study for minimizing the life cycle energy of buildings has been published [7]. The authors stated that in mild climates embodied energy in buildings can represent up to $25 \%$ of the total life cycle energy. In the future when operating energy in buildings will be reduced due to the construction of nearly-zero energy buildings, the ratio of embodied energy to total life cycle energy will be increased. A report on prisons' sustainability has been presented [8]. The authors mentioned that a reduction of energy consumption and carbon emissions are required in prisons in order to increase their sustainability. They set target goals regarding the maximum daily energy consumption in prisons at 45 - $60 \mathrm{KWh}$ /offender. A study of the existing correctional system focusing on the USA has been implemented [9]. The authors stated that the notion of "green prisons" as well as the environmental and energy regulations should be related with the humane treatment of prisoners. They expressed their skepticism on the priority of "greening the correctional buildings" over the issue of social justice.

\subsection{Use of Sustainable Energies in Prisons}

A study regarding the use of a solar thermal system for hot water production in a prison located in Philadelphia, USA has been realized [10]. The author mentioned that the prison hosts 2500 prisoners. Installation of 248 solar panels on the rooftop of their buildings would reduce their energy consumption by $20 \%$ $25 \%$. The cost of fuel used for hot water production as well as the carbon emissions in the prison would also be substantially reduced. An evaluation of the biogas sanitation systems in Nepalese prisons has been made [11]. The authors mentioned that biogas digesters have been installed in three Nepalese prisons fermenting human wastes mixed with kitchen wastes. The digester's daily productivity was $62 \mathrm{NL} /$ person while the methane concentration was at a volume of $57 \%-78 \%$. The produced biogas was used as cooking fuel reducing the fuel's cost in the prisons. An investigation of the possibility of installing a biogas plant processing the organic wastes in Tihar prison in India has been implemented

[12]. The author estimated the organic waste production at $750 \mathrm{~kg} / \mathrm{day}$ and the biogas potential at $67.5 \mathrm{NM}^{3} /$ day. He stated that the payback period of the investment was attractive at 2.16 years. A report on the Santa Rita "green prison" with a capacity of 4000 offenders located nearby San Francisco, USA has been 
published [13]. The authors mentioned that the prison had various renewable energy technology installations including a 1.2 MW solar-PV system, a $1 \mathrm{MW}$ fuel cell with heat recovery while the installation of $2 \mathrm{MW}$ of NaS batteries was planned. They also stated that the installed sustainable energy technologies distributing generation resulted in the minimization of the jail's energy bill as well as its carbon emissions. A study on the energy consumption and carbon emissions in Venizelio hospital located in Crete, Greece has been realized [14]. The author mentioned that its annual energy consumption was at $280 \mathrm{KWh} / \mathrm{m}^{2}$ while the annual carbon emissions due to energy use were at $168 \mathrm{~kg} \mathrm{CO}_{2} / \mathrm{m}^{2}$. He also stated that the use of various renewable energy technologies including solar thermal systems, solar-PV systems, solid biomass burning systems and ground source heat pumps could zero its net annual carbon emissions into the atmosphere. A study for the creation of net zero carbon emissions hotels in the Mediterranean region has been published (Vourdoubas, 2018 [15]). Vourdoubas mentioned that since solar energy is abundant in the Mediterranean region, its use in hotels is suggested. Solar thermal technology for hot water production, and solar-PV technology for electricity generation combined with high efficiency heat pumps, could cover all their energy requirements resulting in carbon-neutral hotels. The "greening" of correction buildings has been investigated [16]. The authors mentioned that prisons are some of the most energy-intensive buildings and offer a great opportunity for energy savings. They also stated that measures towards the improvement of energy behavior in prisons require the participation of all the stakeholders including the offenders. A study regarding the existing four rural prisons in Greece has been made [17]. Among them, one is located in the village of Agia in western Crete. Rural prisons have enough space for the installation of sustainable energy systems generating heat and electricity while the biomass produced in their fields could be used for the production of various energy products.

\subsection{Carbon Sequestration from Tree Plantations}

An investigation of the effect of weeds on net $\mathrm{CO}_{2}$ exchange in an olive tree orchard in Spain has been implemented [18]. The authors compared the net $\mathrm{CO}_{2}$ exchange in two olive orchards, one with weed cover and one without. They found that the net annual $\mathrm{CO}_{2}$ exchange in the olive orchard covered with weeds was double that of the other at $0.513 \mathrm{~kg} \mathrm{CO} / \mathrm{m}^{2}$. An estimation of the carbon footprint of an olive tree grove located in central Italy over a period of 11 years has been made [19]. The authors compared carbon sequestration and carbon emissions in the olive tree plantation over this period. They estimated that carbon sequestration exceeded carbon emissions in the fourth year while the net annual carbon sequestration over this period was at $3.45 \mathrm{~kg} \mathrm{CO} / \mathrm{m}^{2}$. A study on $\mathrm{CO}_{2}$ sequestration from olive groves in Southern Spain has been implemented [20]. The authors estimated the net carbon balance in various intensive and conventional olive tree plantations. They mentioned that the annual atmospher- 
ic $\mathrm{CO}_{2}$ removal rate in these olive groves was varying between $0.752 \mathrm{~kg} \mathrm{CO} / \mathrm{m}^{2}$ and $1.503 \mathrm{~kg} \mathrm{CO} / \mathrm{m}^{2}$. Research on the carbon sequestration potential of selected tree species in India using a dynamic growth model has been realized [21]. The authors found that the net annual carbon sequestration rate for fast growing species was $2.93 \mathrm{~kg} \mathrm{CO} / \mathrm{m}^{2}$ for poplar and $2.2 \mathrm{~kg} \mathrm{CO} / \mathrm{m}^{2}$ for Eucalyptus. An investigation on carbon storage in Eucalyptus plantations in Southern China has been made [22]. The authors mentioned that Eucalyptus plantations stored carbon in both the above- and underground fractions while the annual carbon sequestration rate over an eight-year period was $3.23 \mathrm{~kg} \mathrm{CO} / \mathrm{m}^{2}$. They also stated that Eucalyptus may deplete fast soil nutrients and they suggested the development of mixed forest communities for improving the ecosystem's sustainability. Published data regarding energy consumption and carbon emissions in various prisons are presented in Table 1. Published data regarding carbon removal from tree plantations are presented in Table 2.

The aims of the current work are:

1) Investigation of the possibility of using renewable energy technologies for covering all the energy needs in prisons in Crete, and

Table 1. Energy consumption and carbon emissions in prisons and correction buildings.

\begin{tabular}{|c|c|c|c|}
\hline Source & $\begin{array}{l}\text { Annual energy } \\
\text { consumption }\end{array}$ & $\begin{array}{l}\text { Annual } \\
\text { carbon emissions }\end{array}$ & $\begin{array}{l}\text { Share of electricity } \\
\text { in total energy use }\end{array}$ \\
\hline $\begin{array}{l}\text { Christoforidis } \\
\text { et al., } 2014\end{array}$ & $\begin{array}{c}4000-16,500 \\
\text { KWh/prisoner }\end{array}$ & $0.6-4$ tn $\mathrm{CO}_{2} /$ prisoner & \\
\hline $\begin{array}{l}\text { Christoforidis } \\
\text { et al., } 2014 \\
\text { (Greek prisons) }\end{array}$ & $4000 \mathrm{KWh} /$ prisoner & 1.2 tn $\mathrm{CO}_{2} /$ prisoner & \\
\hline Petroliagki, 2018 & $\begin{array}{l}663.48 \mathrm{KWh} / \mathrm{m}^{2} \\
\text { (primary energy consumption) }\end{array}$ & & $73.41 \%$ \\
\hline Lunn, 2014 & $\begin{array}{c}293.6 \mathrm{KWh} / \mathrm{m}^{2} \\
\text { (on-site energy consumption) } \\
535.2 \mathrm{KWh} / \mathrm{m}^{2} \\
\text { (primary energy consumption) }\end{array}$ & & \\
\hline LeRoy et al., 2012 & $14,600-21,900 \mathrm{KWh} /$ prisoner & & \\
\hline
\end{tabular}

Table 2. Atmospheric carbon removal rate in tree plantations.

\begin{tabular}{ccc}
\hline Author/date & Tree plantation & Annual $\mathrm{CO}_{2}$ removal rate $\left(\mathrm{kg} \mathrm{CO}_{2} / \mathrm{m}^{2}\right)$ \\
\hline Chamizo et al., 2017 & Olive & 0.513 \\
Proietti et al., 2014 & Olive & 3.45 \\
Lopez-Bellido et al., 2016 & Olive & $0.752-1.503$ \\
Kaul et al., 2010 & Poplar & 2.93 \\
Kaul et al., 2010 & Eucalyptus & 2.2 \\
Du et al., 2015 & Eucalyptus & 3.23 \\
\hline
\end{tabular}


2) Estimation of the size and cost of the required renewable energy systems as well as the area of the required tree plantations for carbon sequestration for achieving a net zero carbon emissions prison located in Crete, Greece.

The methodology followed includes:

1) the use of existing data regarding the energy consumption in prisons and the share of electricity in their energy mix, 2) investigation of various renewable energy technologies which could be used in Cretan prisons, 3) implementation of a case study regarding zeroing net carbon emissions in a Cretan prison, estimating the size of the proposed renewable energy systems and the area of the tree plantation required for carbon sequestration, and 4) presentation of existing opportunities and barriers for greening the prisons in Crete. Uncertainties in the current study are related with the limited published data regarding energy consumption and carbon emissions in Greek prisons and correction buildings.

\section{Energy Consumption in Prisons}

\subsection{Operational Energy}

Prisons consume energy in various sectors including space heating and cooling, hot water production, lighting and operation of various electric machinery and devices. Specific energy consumption in prisons varies and it depends on the type of construction of the building, the local climate and the kind of prison. Although, to my best knowledge, there are no published data regarding life cycle energy consumption in prison buildings, it will be assumed that they follow the same pattern like other buildings and their operational energy has a share of approximately $85 \%$ of their life cycle energy consumption. Annual energy consumption in Greek prisons has been reported at $4000 \mathrm{KWh} /$ prisoner while their annual carbon emissions are at 1.2 tn $\mathrm{CO}_{2}$ /prisoner. It should be noted that the reported energy consumption in European and USA prisons is considerably higher than the values reported for Greek prisons.

\subsection{Embodied Energy}

The energy consumed during the prison's construction, renovations and demolition is called embodied energy and it is assumed that it corresponds at $15 \%$ of their life cycle energy use. Embodied energy in Greek prisons is estimated at 706 $\mathrm{KWh}$ /prisoner per year. The fraction of embodied energy to life cycle energy use in conventional buildings is relatively low. However, if prison buildings are transformed to nearly-zero energy buildings and their operational energy will be reduced, then the fraction of the embodied energy to life cycle energy use would be increased. Taking into account that the operational energy use is 4000 $\mathrm{KWh} /$ prisoner and the embodied energy use is $706 \mathrm{KWh} /$ prisoner it is concluded that the annual life cycle energy use in Greek prisons is $4706 \mathrm{KWh} /$ prisoner.

\section{Possibilities of Using Renewable Energy Technologies in Cretan Prisons}

Various renewable energy technologies which are mature, reliable and cost-effective 
could be used in Cretan prisons for covering their energy requirements in heat, cooling and electricity. These include:

1) Solar thermal energy for hot water production,

2) Solar-PV energy for electricity generation,

3) Solid biomass burning for heat generation, and

4) High efficiency heat pumps for space heating and cooling.

Solar energy is broadly used in the Mediterranean region for hot water production in buildings with simple thermosiphonic systems and flat plate collectors. Solar-PV energy is used for electricity generation in grid-connected buildings particularly during the last decade when the cost of solar panels has been substantially decreased and the generation of electricity has become profitable. Net-metering regulations allow for the storage of electricity into the grid when it is not needed in the building. Solid biomass is used for heat generation by burning either in stoves or in open fires. Finally, high efficiency heat pumps are broadly used for heat and cooling generation. Renewable energy technologies which could be used in Cretan prisons are presented in Table 3.

\section{Requirements for Net Zero Carbon Emissions Prisons}

Prisons, like other buildings, are obliged to reduce their energy consumption and replace the use of fossil fuels with renewable energies. Many sustainable energy technologies are currently mature, reliable and cost-effective, which could be used for that. For being carbon neutral due to operational energy use, a prison should:

1) Reduce its energy consumption using energy-saving techniques,

2) Replace all the fossil fuels used with renewable energies like solar energy or biomass,

3) Generate the same amount of grid electricity used annually with the green electricity generated, preferably with solar-PV panels according to the net-metering regulations. The solar panels could be installed either on-site or off-site of its premises,

4) Alternatively, carbon emissions due to fossil fuels use could be offset by the creation of tree plantations which sequestrate atmospheric carbon equal to the emitted quantities.

If a prison complies with the abovementioned requirements, it could zero its net annual carbon emissions into the atmosphere due to energy use.

Table 3. Renewable energy technologies which could be used for energy generation in Cretan prisons.

\begin{tabular}{|c|c|c|c|c|c|}
\hline Energy source & Technology & $\begin{array}{c}\text { Space } \\
\text { heating }\end{array}$ & $\begin{array}{l}\text { Hot water } \\
\text { production }\end{array}$ & $\begin{array}{l}\text { Space } \\
\text { cooling }\end{array}$ & $\begin{array}{l}\text { Electricity } \\
\text { generation }\end{array}$ \\
\hline Solar energy & $\begin{array}{l}\text { Flat plate collectors-thermosiphonic } \\
\text { systems }\end{array}$ & & Yes & & \\
\hline Solar energy & Photovoltaics & & & & Yes \\
\hline Solid biomass & Burning & Yes & Yes & & \\
\hline Ambient heat & High efficiency heat pumps & Yes & Yes & Yes & \\
\hline
\end{tabular}




\section{A Case Study of a Net Zero Carbon Emissions Prison Located in Crete, Greece}

For achieving a net zero carbon emissions prison in Crete, Greece, two scenarios have been examined. In the first scenario solar energy systems will generate annually all the required energy in the prison, eliminating the need for fossil fuels or electricity derived from them. In the second scenario, half the required energy in the prison will be generated by solar energy and the other half by fossil fuels. Additionally, a tree plantation will be created, which will sequestrate annually the same amount of carbon that is emitted by the fossil fuels used in the prison.

\subsection{Estimation of the Size of Solar Energy Systems Generating All the Energy Required in the Prison}

The possibility of zeroing the net carbon emissions in Agia's prison with a capacity of 178 offenders located in western Crete will be investigated. In the first scenario solar energy systems will be used for generating all the required energy in the prison. In order to size the required renewable energy systems, the following assumptions have been made:

1) The fuels currently used in the prison are electricity and diesel oil, as used in hot water production. The specific annual energy consumption in the prison is $4000 \mathrm{KWh} /$ offender while $25 \%$ of its energy consumption is used for hot water production and the remaining $75 \%$ for lighting and for powering electric devices including the equipment used for space heating and cooling, which use $40 \%$ of the overall electricity consumption.

2) The sustainable energy systems that will be used in the prison include: A solar thermal system for hot water production, a solar-PV system for electricity generation, and a high efficiency heat pump for air conditioning. There is enough space availability for installing the solar energy systems required, since Agia prison is an agricultural prison.

3) The above-mentioned sustainable energy systems will generate annually all the energy required when the prison is full. The prison is grid-connected and the generated electricity, when it is not needed, will be stored in the grid according to net-metering regulations.

4) The solar thermal system with flat plate collectors will produce $80 \%$ of the hot water requirements while the remaining $20 \%$ will be produced with electricity.

5) Energy renovation in the prison will result in a $20 \%$ decrease in the overall energy consumption, which will be distributed equally in all sectors.

6) Annual electricity generation will be made by a solar-PV system in Crete, at $1500 \mathrm{KWh} / \mathrm{KW}_{\mathrm{p}}$, annual heat generation by a solar thermal system in Crete, at $500 \mathrm{KWh}_{\text {th }}$ per $\mathrm{M}^{2}$ of flat plate collectors, with a capital cost of a solar-PV system at $1200 € / \mathrm{KW}_{\mathrm{p}}$, and the capital cost of a solar thermal system at $300 €$ per $\mathrm{M}^{2}$ of collectors.

The size of the solar energy systems generating all the required energy in Agia prison is presented in Table 4. 
Table 4. Size of the solar energy systems which could zero the net annual carbon emissions in Agia prison in Crete, Greece.

\begin{tabular}{cc}
\hline Parameter & Value \\
\hline Initial annual energy consumption & $712,000 \mathrm{KWh}$ \\
Annual energy consumption after energy refurbishment & $569,600 \mathrm{KWh}$ \\
Annual electricity use in all sectors except hot water production & $427,200 \mathrm{KWh}_{\mathrm{el}}$ \\
Annual requirements for hot water production & $142,400 \mathrm{KWh}_{\mathrm{th}}$ \\
Annual electricity requirements for hot water production & $28,480 \mathrm{KWh}_{\mathrm{el}}$ \\
Annual heat generation by the solar thermal system & $113,920 \mathrm{KWh}_{\mathrm{th}}$ \\
Total annual electricity requirements & $455,680 \mathrm{KWh}_{\mathrm{el}}$ \\
Size of a solar-PV system & $303.8 \mathrm{KW}_{\mathrm{p}}$ \\
Size of a solar thermal system-area of flat plate collectors & $227.8 \mathrm{M}^{2}$ \\
Capital cost of the solar-PV system & $364,560 €$ \\
Capital cost of the solar thermal system & $68,340 €$ \\
Onital cost of both solar energy systems & $432,900 €$ \\
Annual carbon emissions due to heating oil use & $2432 €$ \\
Annual carbon emissions due to grid electricity use & $38.45 \mathrm{tn} \mathrm{CO}_{2}$ \\
Annual total carbon emissions due to conventional fuel use & $256.32{\mathrm{tn} \mathrm{CO}_{2}}^{2}$ \\
\hline Overall annual carbon emissions per offender due to conventional fuel use & $294.77{\mathrm{tn} \mathrm{CO}_{2}}^{1.66} \mathrm{tn} \mathrm{CO}_{2}$ \\
\hline
\end{tabular}

${ }^{1}$ Carbon emissions, heating oil use, $0.27 \mathrm{~kg} \mathrm{CO}_{2} / \mathrm{KWh} ;{ }^{2}$ Carbon emissions, grid electricity, $0.6 \mathrm{~kg} \mathrm{CO} / \mathrm{KWh}$.

\subsection{Estimation of the Size of the Solar Energy Systems and the Area of the Tree Plantation Which, When Combined, Could Zero the Net Carbon Emissions in the Prison}

In the second scenario it is assumed that the solar energy systems will generate half the required energy in the prison while the rest will be produced by fossil fuels. Tree plantations either with olive trees or by Eucalyptus trees will be created for the sequestration of the $\mathrm{CO}_{2}$ emissions. The size of the solar energy systems and the area of the required tree plantations are presented in Table 5.

\section{Opportunities and Barriers in "Greening" Cretan Prisons}

Existing opportunities for the creation of net zero carbon emissions prisons in Crete are due to the fact that:

1) European policy promotes the creation of nearly zero energy buildings which also have nearly zero or zero carbon emissions prioritizing public buildings,

2) Net-metering regulations allow the generation of solar green electricity in the prisons and its storage into the grid when it is not needed,

3) Various solar energy technologies for heat and electricity generation could assist in the creation of net zero carbon emissions prisons. They are mature, reliable and cost-effective while solar energy irradiance is high in Crete, and 
Table 5. Size of the solar energy systems which will generate half the required energy while the $\mathrm{CO}_{2}$ emitted by fossil fuels will be offset by a tree plantation.

\begin{tabular}{|c|c|}
\hline Parameter & Value \\
\hline Annual electricity use in all sectors except hot water production & $213,600 \mathrm{KWh}_{\mathrm{el}}$ \\
\hline Annual requirements for hot water production & $71,200 \mathrm{KWh}_{\mathrm{th}}$ \\
\hline Annual electricity requirements for hot water production & $14,240 \mathrm{KWh}_{\mathrm{el}}$ \\
\hline Annual heat generation by the solar thermal system & $56,960 \mathrm{KWh}_{\mathrm{th}}$ \\
\hline Total annual electricity requirements & $227,840 \mathrm{KWh}_{\mathrm{el}}$ \\
\hline Size of a solar-PV system & $151.9 \mathrm{KW}_{\mathrm{p}}$ \\
\hline Size of a solar thermal system-area of flat plate collectors & $113.9 \mathrm{M}^{2}$ \\
\hline Capital cost of the solar-PV system & $182,280 €$ \\
\hline Capital cost of the solar thermal system & $34,170 €$ \\
\hline Capital cost of both solar energy systems & $216,450 €$ \\
\hline Overall capital cost per offender & $1216 €$ \\
\hline Annual carbon emissions due to heating oil use ${ }^{1}$ & 19.225 tn $\mathrm{CO}_{2}$ \\
\hline Annual carbon emissions due to grid electricity use ${ }^{2}$ & 128.165 tn $\mathrm{CO}_{2}$ \\
\hline Annual total carbon emissions due to conventional fuel use & 147.385 tn $\mathrm{CO}_{2}$ \\
\hline Overall annual carbon emissions per offender due to conventional fuel use & 0.83 tn $\mathrm{CO}_{2}$ \\
\hline Area of an olive tree plantation sequestrating all carbon emissions ${ }^{3}$ & 14.74 ha \\
\hline Area of a Eucalyptus tree plantation sequestrating all carbon emissions ${ }^{4}$ & 5.9 ha \\
\hline
\end{tabular}

${ }^{1}$ Carbon emissions, heating oil use, $0.27 \mathrm{~kg} \mathrm{CO}_{2} / \mathrm{KWh}^{2}{ }^{2}$ Carbon emissions, grid electricity, $0.6 \mathrm{~kg} \mathrm{CO} / \mathrm{KWh}$; ${ }^{3}$ Annual carbon sequestration by olive trees, $1 \mathrm{~kg} \mathrm{CO} / \mathrm{m}^{2} ;{ }^{4}$ Annual carbon sequestration by Eucalyptus trees, $2.5 \mathrm{~kg} \mathrm{CO}_{2} / \mathrm{m}^{2}$.

4) There are financial instruments like third-party financing through energy service companies which could finance the implementation of energy renovation projects in prisons.

There are various internal weaknesses in Greek prisons, negatively influencing their "greening", which include:

1) Lack of financial resources due to current economic crisis in Greece,

2) Lack of technical expertise and staff required for supervision and maintenance of the sustainable energy systems installed in the prisons, and

3) Lack of organizational flexibility and required human capacity in them.

\section{Discussion}

Estimations regarding the use of solar energy systems for energy generation in Agia's prison in Crete, Greece have been implemented. Additionally the area of a tree plantation offsetting carbon emissions due to fossil fuels use in the prison has been calculated. These estimations regarding the rural prison in Agia, Crete indicated that the creation of net zero carbon emissions correctional buildings due to energy use are feasible in Crete, Greece. This could be achieved with the 
combined use of solar energy technologies, which are currently cost-effective and broadly used. Additionally, carbon emissions offsetting with the creation of tree plantations sequestrating atmospheric carbon could be used. The obtained results could be used for the energy renovation of the existing prison buildings in Crete in compliance with the current Greek and EU legislation. Prisoners could be engaged in the operation and maintenance of the installed solar energy systems and probably in the planting and irrigation of the tree plantations. They could also be trained in sustainable energy technologies through seminars organized inside the prison in order to increase their knowledge and skills in these benign energy technologies. The acquired knowledge and skills could assist them in their future employment. Further work should be focused on an accurate estimation of the energy consumption in Cretan prisons and its distribution in each sector. A cost-benefit analysis of the investment in the required sustainable energy systems achieving net zero carbon emissions due to energy use in them would be useful for their future energy refurbishment.

\section{Conclusion}

The possibility of zeroing the net annual carbon emissions due to operational energy use in Cretan prisons with reference to the agricultural prison in Agia has been examined. Additionally the size and the cost of the required renewable energy systems for achieving that have been estimated. Finally the area of the required tree plantation for offsetting carbon emissions due to fossil fuels use in the prison has been calculated. It has been indicated that with the use of mature, reliable and cost-effective solar energy technologies for heat and electricity generation, the annual net carbon emissions due to energy use in Agia's prison could be zeroed. Additionally, tree plantations could be created for offsetting any $\mathrm{CO}_{2}$ emitted into the atmosphere due to fossil fuels use. The capacity of Agia's prison is 178 offenders, its annual operational energy consumption is at 4000 $\mathrm{KWh}$ /prisoner, while its annual $\mathrm{CO}_{2}$ emissions due to fossil fuels use are at 1.66 $\mathrm{kg} \mathrm{CO}_{2} /$ prisoner. The surface of the flat plate solar collectors in the required solar thermal system has been estimated at $113.9 \mathrm{M}^{2}$ to $227.8 \mathrm{M}^{2}$ while its cost is estimated at $34,170 €$ to $68,340 €$. The nominal power of the solar-PV system has been estimated at $151.9 \mathrm{KW}_{\mathrm{p}}$ to $303.8 \mathrm{KW}_{\mathrm{p}}$ while its cost is estimated at $182,280 €$ to $364,560 €$. The area of the tree plantation sequestrating $50 \%$ of the annual $\mathrm{CO}_{2}$ emissions due to fossil fuels use in the prison has been estimated at 14.74 ha for olive trees and at 5.9 ha for Eucalyptus trees. The results indicated that the energy refurbishments of Agia's agricultural prison in Crete, Greece in order to zero its annual net carbon emissions due to energy use are feasible with the use of existing solar energy technologies.

\section{Acknowledgements}

I would like to thank my colleagues in MAICH for their support in my research, particularly Mrs. Maria Verivaki for reading the paper and making positive 
comments on it.

\section{Conflicts of Interest}

The author declares no conflicts of interest regarding the publication of this paper.

\section{References}

[1] Christoforidis, G.C., Papagiannis, G.K., Brain, M. and Puksec, T. (2014) Establishing an Assessment Framework for Energy Sustainability in Prisons: The E-SEAP Project. 14th International Conference on Environment and Electrical Engineering (EEEIC), Krakow, Poland, 10-12 May 2014. https://doi.org/10.1109/EEEIC.2014.6835861

[2] Petroliagki, M. (2018) Energy Consumption Profile of the Existing Building Stock in Greece, Greek Ministry of Environment and Energy.

http://bpes.ypeka.gr/wp-content/uploads/2018_03_03.PRESENTATION_ENERGY POVERTY-\%CE\%94\%CE\%99\%CE\%9F\%CE\%A1\%CE\%98\%CE\%A9\%CE\%9C\%C E\%95\%CE\%9D\%CE\%9F.pdf

[3] Lunn, M. (2014) Energy Efficiency in Correctional Facilities and Opportunities for State Energy Office Engagement. U.S. Department of Energy, Energy Efficiency and Renewable Energy. https://www.energy.gov/sites/prod/files/2014/05/f15/tap_corrections_presentation. pdf

[4] Correction Buildings in Crete (2017) (In Greek). https://www.cretapost.gr/347105/aktinografia-ton-sofronistikon-katastimaton-tis-k ritis/

[5] Torcellini, P., Pless, S., Deru, M. and Crawley, D. (2006) Zero Energy Buildings: A Critical Look at the Definition. National Laboratory of the US Department of Energy, Pacific Grove, CA.

[6] Ramesh, T., Prakash, R. and Shukla, K.K. (2010) Life Cycle Energy Analysis of Buildings: An Overview. Energy and Buildings, 42, 1592-1600.

https://doi.org/10.1016/j.enbuild.2010.05.007

[7] Karimpour, M., Belusko, M., Xing, K. and Bruno, F. (2014) Minimizing the Life Cycle Energy of Buildings: Review and Analysis. Building and Environment, 73, 106-114. https://doi.org/10.1016/j.buildenv.2013.11.019

[8] LeRoy, C.J., Bush, K., Trivett, J. and Gallagher, B. (2012) The Sustainability in Prisons Project. An Overview (2004-2012).

http://sustainabilityinprisons.org/wp-content/uploads/2016/02/Overview-cover-text -reduced-size.pdf

[9] Moran, D. and Jewkes, Y. (2014) “Green" Prisons Rethinking the "Sustainability" of the Carceral Estate. Geographica Helvetica, 69, 345-353.

https://doi.org/10.5194/gh-69-345-2014

[10] Eskind, R. (2009) Solar Hot Water System Installed in Philadelphia Prison. Corrections Today, 68-72.

[11] Lohri, C., Vogeli, Y., Oppliger, A. Mardini, R. Giusti, A. and Zurbrugg, C. (2010) Evaluation of Biogas Sanitation Systems in Nepalese Prisons. Decentralized Wastewater Treatment Solutions in Developing Countries Conference and Exhibition, Surabaya, Indonesia, 23-26 March 2010.

https://www.researchgate.net/publication/229010430_Evaluation_of_Biogas_Sanitat 
ion_Systems_in_Nepalese_Prisons https://doi.org/10.2166/wpt.2010.093

[12] Krishnan, A. (2015) A Study of Challenges, Opportunities and Feasibilities of Installation of Biogas Plants Across Two Institutions: A Case Study of a Jail and a Zoo. https://www.academia.edu/34542424/A_STUDY_OF_CHALLENGES_OPPORTUN ITIES_AND_FEASIBILITIES_OF_INSTALLATION_OF_BIOGAS_PLANTS_ACR OSS_TWO_INSTITUTIONS_-A_CASE_STUDY_OF_A_JAIL_AND_A_ZOO

[13] Marnay, C., DeForest, N., Stadler, M., Donadee, J., Dierckxsens, C., Mendes, G., Lai, J. and Ferreira Cardose, G. (2011) A Green Prison: Santa Rita Jail Creeps towards Zero Net Energy. ECEEE Summer Study, Belambra Presquile de Giens, France. https://escholarship.org/uc/item/9xz7c3nz https://doi.org/10.1109/PESGM.2012.6345235

[14] Vourdoubas, J. (2018) Energy Consumption and Carbon Emissions in Venizelio Hospital in Crete, Greece: Can It Become Carbon Neutral? Journal of Engineering and Architecture, 6, 19-27. https://doi.org/10.11114/set.v6i1.4013

[15] Vourdoubas, J. (2018) Hotels with Net Zero Carbon Emissions in the Mediterranean Region: Are They Feasible? Journal of Tourism and Hospitality Management, 6, 72-79. https://doi.org/10.15640/jthm.v6n2a6

[16] Cross, J.E., O’Conner Shelley, T. and Mayer, A.P. (2017) Putting the Green into Corrections: Improving Energy Conservation, Building Function, Safety and Occupant Well-Being in an American Correction Facility. Energy Research and Social Science. https://doi.org/10.1016/j.erss.2017.06.020

[17] Schizas, P. (2013) Rural Prisons in Greece. Ph.D. Thesis, Panteion University of Social and Political Sciences, Athens, Greece (In Greek). http://thesis.ekt.gr/thesisBookReader/id/28700\#page/10/mode/2up

[18] Chamizo, S., Serrano-Ortiz, P., Lopez-Ballesteros, A., Sanchez-Canete, E.P., Vicente-Vicente, J.L. and Kowalski, A.S. (2017) Net Ecosystem $\mathrm{CO}_{2}$ Exchange in an Irrigated Olive Orchard of SE Spain: Influence of Weed Cover. Agriculture, Ecosystems and Environment, 239, 51-64. https://doi.org/10.1016/j.agee.2017.01.016

[19] Proietti, S., Sdringola, P., Desideri, U., Zepparelli, F., Brunori, A., Ilarioni, L., Nasini, L., Regni, L. and Proietti, P. (2014) Carbon Footprint of an Olive Tree Grove. Applied Energy, 127, 115-124. https://doi.org/10.1016/j.apenergy.2014.04.019

[20] Lopez-Bellido, P.J., Lopez-Bellido, L., Fernandez-Garcia, P., Munoz-Romero, V. and Lopez-Bellido, F.J. (2016) Assessment of Carbon Sequestration and the Carbon Footprint in Olive Groves in Southern Spain. Carbon Management, 7, 161-170. https://doi.org/10.1080/17583004.2016.1213126

[21] Kaul, M., Mohren, G.M.J. and Dadhwal, V.K. (2010) Carbon Storage and Sequestration Potential of Selected Tree Species in India. Mitigation and Adaptation Strategies for Global Change, 15, 489-510. https://doi.org/10.1007/s11027-010-9230-5

[22] Du, H., Zeng, F., Peng, W., Wang, K., Zhang, H., Liu, L. and Song, T. (2015) Carbon Storage in a Eucalyptus Plantation Chronosequence in Southern China. Forests, 6 , 1763-1778. https://doi.org/10.3390/f6061763 